\title{
Active and passive remote sensing for monitoring the planetary boundary layer height
}

\section{Monitorización de la altura de la capa límite mediante teledetección activa y pasiva}

\author{
J. L. Corredor-Ardoy(*), J. A. Bravo-Aranda, M. J Granados-Muñoz, J. L. Guerrero-Rascado, \\ J. Fernández-Gálvez, A. Cazorla, L. Alados-Arboledas \\ Department of Applied Physics, University of Granada, Fuentenueva s/n, Granada, Spain \\ Andalusian Institute for Earth System Research (IISTA), Av. del Mediterráneo s/n, Granada, Spain \\ ${ }^{*}$ Email: junlu@correo.ugr.es \\ Received / Recibido: 14/12/2013. Revised / Revisado: 12/04/2014. Accepted / Aceptado: 14/04/2014 \\ DOI: http://dx.doi.org/10.7149/OPA.47.2.83
}

\begin{abstract}
:
The planetary boundary layer (PBL) is the lowest part of the atmosphere directly influenced by its contact with the land surface and it usually responds to changes in surface forcing in a time scale of an hour or less. Continuous monitoring of its height is highly important for atmospheric and environmental sciences. This work presents continuous monitoring of the PBL height (PBLH) using active (lidar and ceilometer) and passive (microwave radiometer, MWR) remote sensing instruments. Both methodologies are suitable for continuous monitoring of the planetary boundary layer under almost all weather conditions during daytime but, at nighttime ceilometer- and lidarbased techniques are limited due to the overlap of the instruments and MWR-based techniques are not always applicable due to lack of convection. The wavelet covariance transform method is applied to lidar and ceilometer data, optimizing in each case the detection of the PBL during daytime. Independent estimates using the parcel method with temperature profiles from a co-located passive MWR are used for comparison. Validation of both active and passive remote sensing techniques is performed at times when radiosoundings are available.
\end{abstract}

Key words: Ceilometer, Lidar, Microwave Radiometry, Planetary Boundary Layer, Radiosounding, Ranged Corrected Signal, Wavelet Covariance Transform.

\section{RESUMEN:}

La capa límite planetaria (PBL) es la parte de la atmósfera que está directamente influenciada por la presencia de la superficie de la Tierra, y responde a forzamientos superficiales en una escala de horas o incluso menos. La monitorización continua de la altura de la capa límite es de gran importancia para las ciencias atmosféricas y ambientales. Este trabajo presenta monitorizaciones continuas de la altura de PBL usando instrumentos de medida de teledetección tanto activa (lidar y ceilómetro) como pasiva (radiómetro de microondas). Ambas metodologías son válidas para la monitorización continua de la PBL durante el día, bajo la mayoría de condiciones meteorológicas. En cambio durante la noche las tecnologías tipo lidar están limitadas por el solapamiento del instrumento, mientras que la técnicas utilizadas con radiómetro de microondas no siempre son aplicables debido a la falta de condiciones convectivas. El método wavelet covariance transform es aplicado a los datos obtenidos mediante lidar y ceilómetro, optimizando en cada caso la detección de la PBL durante el día. Por otro lado estos datos se han comparado con estimaciones de la altura de la PBL obtenidas mediante el método de la parcela a partir de los perfiles de temperatura obtenidos por un radiómetro de microondas pasivo. La validación de ambos métodos, activos y pasivos, se realiza mediante radiosondeos, siempre que están disponibles.

Palabras clave: Capa Límite Planetaria, Ceilómetro, Lidar, Radiómetro de Microondas, Radiosondeo, Wavelet Covariance Transform. 


\section{REFERENCES AND LINKS / REFERENCIAS Y ENLACES}

[1]. R. B. Stull, An Introduction to Boundary Layer Metereology, Kluwer Acad., Dordrecht, Netherlands (1988). DOI

[2]. P. Seibert, F. Beyrich, S.-E. Gryning, S. Joffre, A. Rasmussen, D. García-Vizcaino, "Review and intercomparison of operational methods for the determination of the mixing height", Atmos. Environ. 34 101-1027 (2000). DOI

[3]. C. Münkel, N. Eresmaa, J. Räsänen, A. Karppinen, "Retrieval of mixing height and dust concentration with lidar ceilometers", Bound.-Lay. Meteorol. 124, 117-128 (2007). DOI

[4]. G. Martucci, C. Milroy, C. D. O'Dowd, "Detection of cloud-base height using Jenoptik CHM15K and Vaisala CL31 ceilometers", J. Atmos. Oceanic Technol. 27, 305-318 (2010). DOI

[5]. M. Wiegner, A. Geiß, "Aerosol profiling with the Jenoptik ceilometer CHM15kx", Atmos. Meas. Tech. 5, 1953-1964 (2012). DOI

[6]. M. Pandolfi, G. Martucci, X. Querol, A. Alastuey, F. Wilsenack, S. Frey, C. D. O’Dowd, M. Dall'Osto, "Continuous atmospheric boundary layer observations in the coastal urban area of Barcelona, Spain", Atmos. Chem. Phys. 13, 345-377 (2013). DOI

[7]. F. Haeffelin, F. Angelini, Y. Morille, G. Martucci, S. Frey, G. P. Gobbi, S. Lolli, C. D. O’Dowd, L. Sauvage, I. Xueref-Rémy, B. Wastine, D. G. Feist, "Evaluation of mixing-height retrievals from automatic profiling lidars and ceilometers in view of future integrated networks in Europe", Bound.-Lay. Meterol. 143, 49-75 (2011). DOI

[8]. M. J. Granados-Muñoz F. Navas-Guzmán, J. A. Bravo-Aranda, J. L. Guerrero-Rascado, H. Lyamani, J. Fernández-Gálvez, L. Alados-Arboledas, "Automatic determination of the planetary boundary layer height using lidar: One-year analysis over southeastern Spain", J. Geophys. Res. 117, D18208 (2012). DOI

[9]. H. Baars, A. Ansmann, R. Engelmann, D. Althausen, "Continuous monitoring of the boundary-lay top with lidar", Atmos. Chem. Phys. 8, 7281-7296 (2008). DOI

[10]. L. Alados-Arboledas, H. Lyamani, F. J. Olmo, "Aerosol size properteis at Armilla, Granada(Spain)", Q. J. R. Meterol Soc. 129, 1395-1413 (2003). DOI

[11]. H. Lyamani, F. J. Olmo, L. Alados-Arboledas, "Physical and optical properties of aerosols over an urban location in Spain: Seasonal and diurnal variability", Atmos. Chem. Phys. 10, 239-254 (2010). DOI

[12]. H. Flentje, B. Heese, J. Reichardt, W. Thomas, "Aerosol profiling using the ceilometers network of the German meteorological service", Atmos. Meas. Tech. Discuss. 3, 3643-3673 (2010). DOI

[13]. C. Milroy, G. Martucci, S. Lolli, S. Loaec, L. Sauvage, I. Xueref-Remy, J. V. Lavrič, P. Ciais, C. D. O'Dowd, "On the ability of pseudo-operational ground-based light detection and ranging (LIDAR) sensors to determine boundary-layer structure: intercomparison and comparison with in-situ radiosounding", Atmos. Meas. Tech. Discuss. 4, 563-597 (2011). DOI

[14]. J. L. Guerrero-Rascado, B. Ruiz Reverter, L. Alados-Arboledas, "Multi-spectral lidar characterization of the vertical structure of Saharan dust aerosol over southern Spain", Atmos. Environ. 42, 2668-2681 (2008). DOI

[15].J. L. Guerrero-Rascado, F. J. Olmo Reyes, I. Avilés-Rodríguez, F. Navas-Guzmán, D. Pérez-Ramírez, H. Lyamani, L. Alados-Arboledas, "Extreme Saharan dust event over the southern Iberian Peninsula in September 2007: Active and passive remote sensing from surface and satellite", Atmos. Chem. Phys. 9, 15673-15723 (2009). DOI

[16]. T. Rose, S. Crewell, U. Löhnert, C. Simmer, "A network suitable microwave radiometer for operational monitoring of the cloudy atmosphere", Atmos. Res. 75, 183-200 (2005). DOI

[17]. C. G. Holzworth, "Estimates of mean maximum mixing depths in the contiguous United States", Mon. Weather Rev. 92, 235-242 (1964). DOI

[18]. D.H.P. Vogelezang, A. A. M. Holtslag, "Evolution and model impact of alternative boundary layers formulations", Boundary Layer Meteorol. 81, 245-269 (1996). DOI

[19]. L. Menut, C. Flamant, J. Pelon, P. H. Flamant, "Evidence of interaction between synoptic and local scales in the surface layer over the Paris area", Boundary Layer Meteorol. 93, 269-286 (1999). DOI 
[20]. J. A. Bravo-Aranda, M. J. Granados-Muñoz, F. Navas-Guzmán, J. L. Guerrero-Rascado, F. J. Olmo, L. Alados-Arboledas, "Lidar depolarization evolution during the CHARMEX intensive field campaign", EAC2013 (2013).

\section{Introduction}

The planetary boundary layer (PBL) is the part of the troposphere directly influenced by the Earth's surface and it responds to surface forcings with a time scale of about an hour or less [1]. The PBL height (PBLH) is highly variable in time and space, ranging from a few hundred meters to several kilometers with diurnal and seasonal cycles. The PBLH and these cycles are fundamental key controlling air pollution because they determine the available volume for pollutants dispersion [2] and are crucial for air quality studies. Continuous PBLH time series is a fundamental issue for climate modeling. The IPCC (Intergovernmental Panel on Climate Change, 2013) declares that the largest uncertainty on climate forecast is due to the current knowledge of atmospheric aerosol effects related with the lack of global aerosol monitoring.

Ceilometers are simply one wavelength backscatter lidars with low pulse energy and high pulse repetition frequencies. Ceilometer were originally designed for cloud base detection, consequently most of the studies based on ceilometers are focused on detecting cloud base heights [3,4]. Improvement in ceilometers hardware has been developed during the last few years, allowing researchers for obtaining continuous high-resolution aerosol backscatter profiles [5-7].

This work presents continuous monitoring of the PBLH using active (lidar and ceilometer) and passive (microwave radiometer) remote sensing instruments. Wavelet covariance transform (WCT) method is applied for lidar data $[8,9]$ and optimized to be used for a Jenoptik ceilometer CHM15k, in order to assess the PBLH. When it is available, PBLH estimations from radiosounding are obtained.

\section{Experimental site and instruments}

Data used in this work were collected at the atmospheric station of the University of
Granada, located on the Andalusian Centre for Environmental Research $\left(37.16^{\circ} \mathrm{N}, 3.61^{\circ} \mathrm{W}, 680\right.$ $\mathrm{m}$ a.s.l.). Granada is a medium-size and a nonindustrialized city of around 250000 inhabitants (twice including its metropolitan area). The city is located in a natural basin surrounded by mountains; the highest mountains are located southeast of the basin with heights above 3000 $\mathrm{m}$ a.s.l. Moreover, it is $200 \mathrm{~km}$ away from the African continent and approximately $50 \mathrm{~km}$ away from the western Mediterranean basin. Due to its location within the Iberian Peninsula, the study area is affected by air masses coming from the Atlantic Ocean, the European and African continents and less frequently from the Mediterranean Sea [10,11].

Vertical range corrected signal (RCS) profiles were measured by a CHM15k-Nimbus (Jenoptik S.A., Germany) ceilometer [6], operating since November 2012. The transmission system consists of a pulsed Nd:YAG with fundamental emission at $1064 \mathrm{~nm}$. The instrument acquires signals in photon counting mode, thus increasing the signal-to-noise ratio from altitude where the concentration of aerosol is low. The full overlap between the emitted laser and receiver field of view is achieved at $1500 \mathrm{~m}$ a.g.l. $[4,12,13]$. However, the CHM15k signal is able to fairly detect aerosol layering at heights above $500 \mathrm{~m}$ a.g.l. [13]. The instrument is nominally operating with a spatial vertical resolution of $15 \mathrm{~m}$ and temporal resolution of $15 \mathrm{~s}$.

The muliwavelength Raman lidar MULHACEN (LR331D400, Raymetrics S.A., Greece), operating in the station since November 2004, was used for profiling the atmospheric aerosol $[14,15]$. It is configured in a monostatic biaxial alignment pointing vertically to the zenith. The transmission system consists of a pulsed Nd:YAG with fundamental emission at $1064 \mathrm{~nm}$. Additional emissions at 532 and 355 $\mathrm{nm}$ are obtained from second and third harmonic generators. The instrument is operating with a spatial vertical resolution of 7.5 $\mathrm{m}$ and temporal resolution on $1 \mathrm{~min}$. The Raman 
lidar was incorporated to EARLINET (European Aerosol Research Lidar NETwork) in April 2005.

Tropospheric temperature and humidity profiles were measured by a ground-based multifrequency passive microwave radiometer, (MWR, RPG-HATPRO, Radiometer Physics $\mathrm{GmbH}$ ) [8]. This instrument performs measurements of the sky brightness temperature in a continuous and automated way with a radiometric resolution between 0.3 and $0.4 \mathrm{~K} \mathrm{RMS}$ at $1.0 \mathrm{~s}$ integration time. The radiometer uses direct detection receivers within two bands: $22-31$ and 51-58 GHz. The first band contains channels providing information about the humidity profile of the troposphere, while the second band contains information about the temperature profile. The retrieval of both temperature and humidity profiles from brightness temperature are done by inversion algorithms [16]. Temperature data are provided with $0.1 \mathrm{~K}$ precision and the accuracy of the temperature retrievals has a mean value of up to $0.8 \mathrm{~K}$ within the boundary layer. Tropospheric profiles are obtained from the surface up to $10 \mathrm{~km}$ using 39 heights with vertical resolution ranging from $10 \mathrm{~m}$ near the surface to $1000 \mathrm{~m}$ for altitudes higher than $7 \mathrm{~km}$. For heights below $3 \mathrm{~km}$ a.s.l., data at 25 points with resolution between 10 and $200 \mathrm{~m}$ are provided.

The radiosounding data were obtained using a GRAW DFM-06 radiosonde (GRAW Radiosondes, Germany), which is a lightweight weather radiosonde that provides temperature (resolution $0.01^{\circ} \mathrm{C}$, accuracy $0.2^{\circ} \mathrm{C}$ ), pressure (resolution $0.1 \mathrm{hPa}$, accuracy $0.5 \mathrm{hPa}$ ), relative humidity (resolution 1\%, accuracy 2\%) and wind (accuracy $0.2 \mathrm{~m} / \mathrm{s}$ ). Data acquisition and processing were performed by Grawmet5 software and a GS-E ground station from the same manufacturer.

Eight months of continuous measurements of collocated MWR and ceilometer have been analyzed. MWR PBLH retrievals based on the parcel method applied to temperature profiles and ceilometer PBLH based on WCT method applied to RCS are presented. The PBLH from the radiosoundings is obtained by means of the parcel [2,17] and the Richardson number methods $[1,18,19]$. The optimized WCT-based method is used to compute the PBLH from lidar and ceilometer.

\section{WCT-method calibration for ceilometer}

Calibration of the WCT-method is based on choosing the proper dilation and threshold values in order to obtain good PBLH estimation [9]. In a previous work [8] the WCT method was successfully applied to lidar data for retrieving PBLH. In this work, this method has been adapted to ceilometer data, choosing as estimation of the PBLH the first maximum of WCT applied to ceilometer RCS higher than a given threshold. The optimum combination of dilation and threshold has been determined, using as reference more than 250 simultaneous lidar retrievals, as 30 meters ( 2 bins) and 0.025 , respectively. To reduce false PBLH, 10-min persistence of PBL estimates has been considered as a reliability criterion, applying different procedures during periods of rising PBL and well developed PBL.

\section{Results}

\subsection{Ceilometer and MWR PBLH evolution at different temporal scales.}

Figure 1 describes the monthly evolution of the maximum values of the PBLH, computed from 14:00 to 15:00 UTC using ceilometer and MWR. Although only eight months are analysed here, there is clear seasonal behaviour with larger values in summer and lower PBLH in winter. The highest PBLH maximum values are retrieved during July according to the ceilometer retrievals, while the peak for the PBLH series determined from MWR measurements is obtained in June. The diagram describing the differences between both PBLH retrievals evidences these differences between both methods. In fact, for most of the year the differences are around zero with a reduce spreading of the differences, excluding the month of March and July. Ceilometer overestimates the PBLH especially for July. In order to go further in these investigations of the 

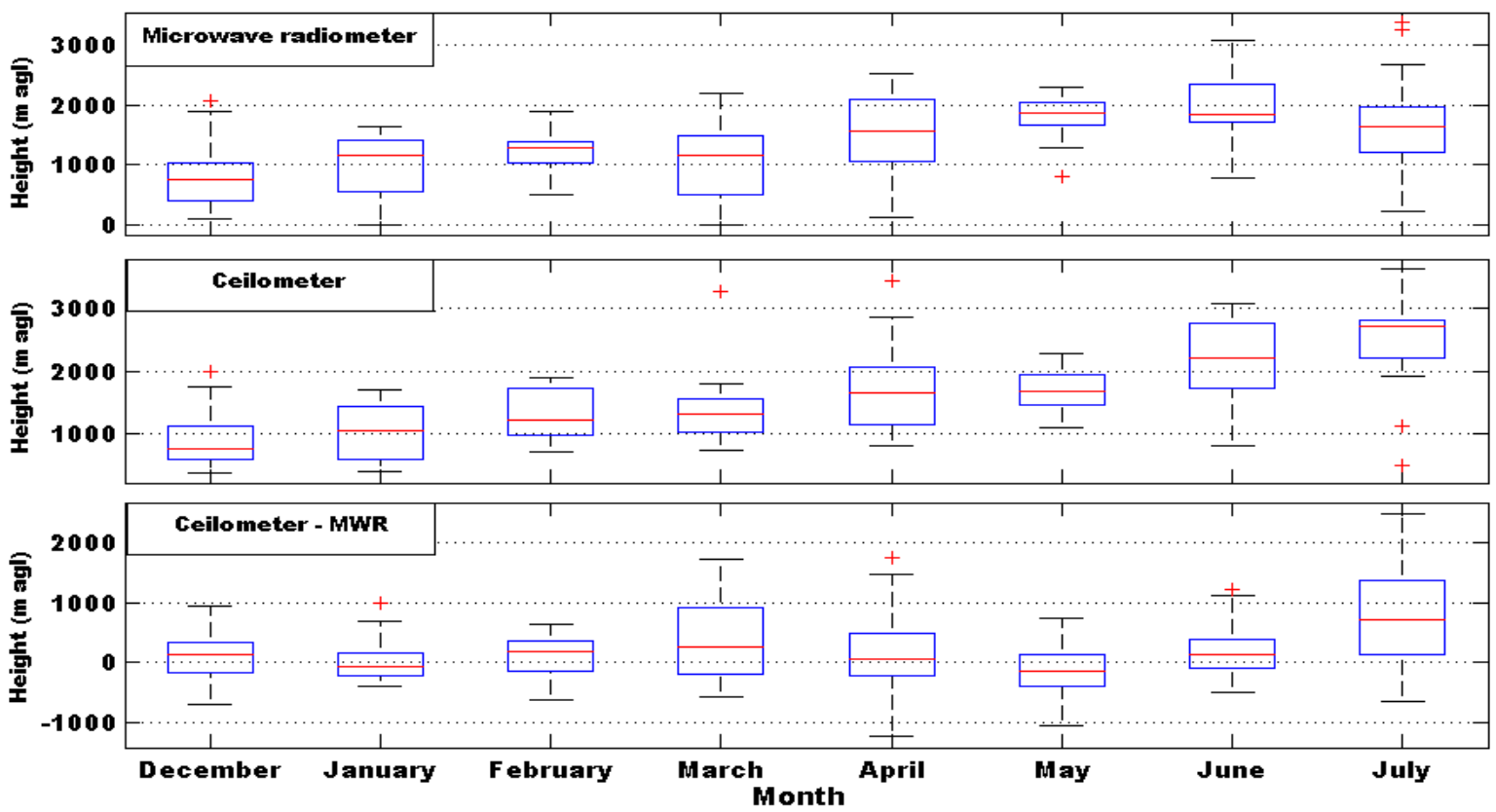

Fig.1. Monthly evolution of maximum PBLH (computed from 14:00 to 15:00) by (a) microwave radiometer (MWR), (b) ceilometer and (c) differences between ceilometer and MWR. The box and whiskers plot describes: red marks inside the boxes represent median of maximum PBLH values, the edges of the boxes are the 25th and 75th percentiles, the whiskers extend to the most extreme data points not considered outliers, and outliers are plotted individually as red crosses.

coincidences and differences between the ceilometer and the MWR PBLH retrievals, additional analyses have been done using other time scales.

Thus, the analysis of diurnal evolution of PBLH estimated by both methods in Fig. 2 offers some insight of PBLH estimation discrepancies between passive and active remote sensing instruments. Values represent median hourly values from PBLH estimation with both methodologies. PBLH results in winter, spring and summer are here represented by February, May and July, respectively. There is an evident disagreement between both methods early in the morning. At this time the ceilometer locates the PBLH higher than the MWR. This difference is due to the ceilometer is detecting the residual layer instead of the PBLH which is located, according to the MWR, below the $500 \mathrm{~m}$, that is below the overlap height of the ceilometer. Along the morning, the retrievals by both methods tend to get close, something that happens early in the afternoon when the maximum PBLH is reached. May values illustrate an effect that can be partially appreciated in the other months: during the morning the MWR estimates a faster growth of the PBLH, while the opposite applies to the ceilometer. This could be explained in terms of the different dynamics of the tracers used to locate the PBLH in each case. In this sense, the aerosol present more inertia than the temperature and thus the PBLH retrieved using the aerosol like a tracer present lower values along the morning. July presents a curious behavior. Particularly, late afternoon values of the PBLH determined by both methods present clear discrepancies, being in this case larger the PBLH derived from ceilometer. A deeper analysis revealed that these results are due to the frequent presence of lofted aerosol layers that been located in the free troposphere can be "trapped" by the growing PBL early in the afternoon, leading to an overestimation of the PBLH that is estimated by the WCT method applied to the ceilometer at the top of the dust layer. This effect was highlighted in the previous study by [8] using lidar RCS profiles. A solution has been proposed using other approaches, like information on depolarization ratio [20]. The next section, where some illustrative study cases are described, offers an insight on this problem. 

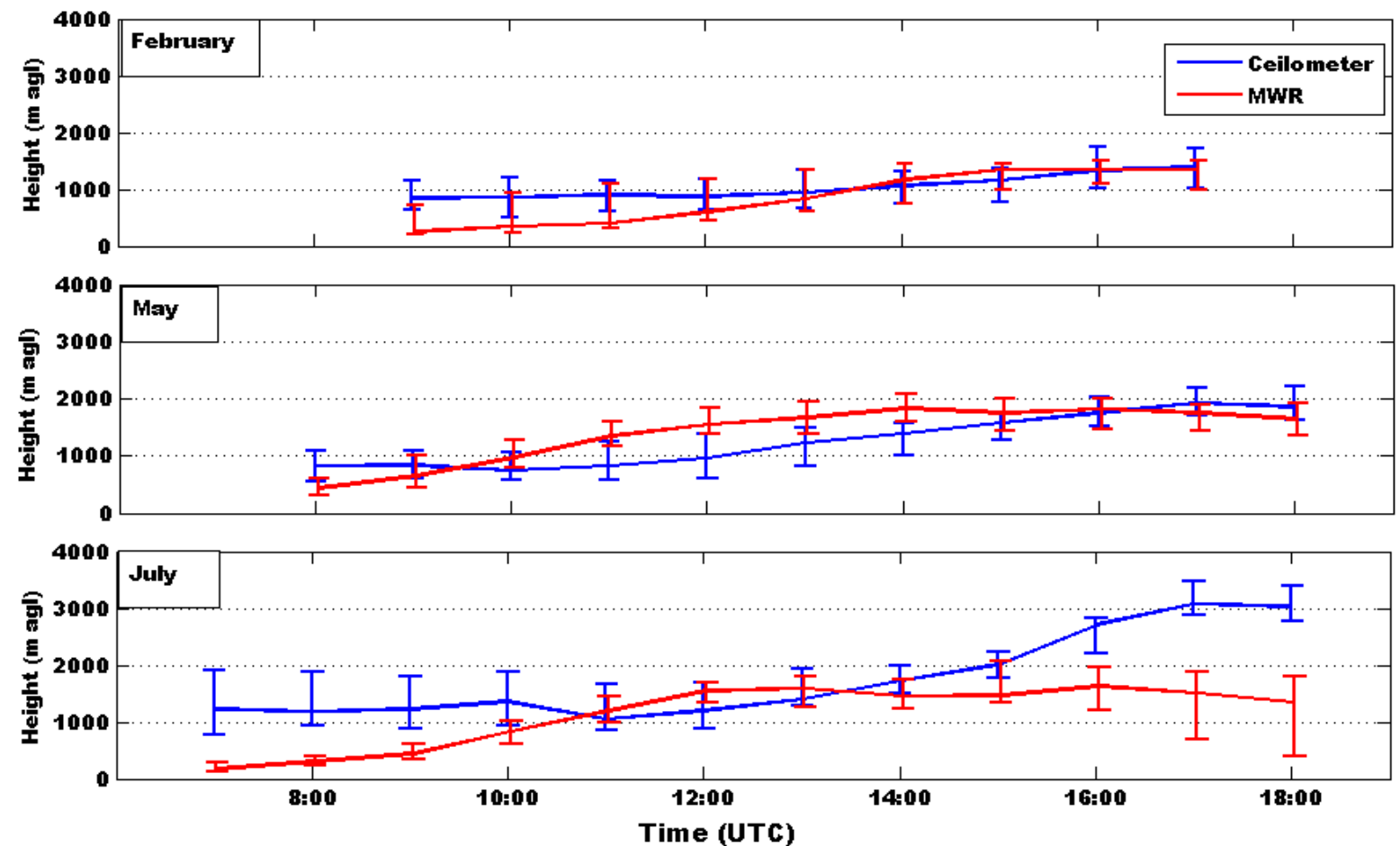

Fig.2. Hourly evolution of PBLH for selected months. Microwave radiometer (MWR) in red and ceilometer in blue. Central values are the median, whiskers correspond to 25 th and 75 th percentiles.

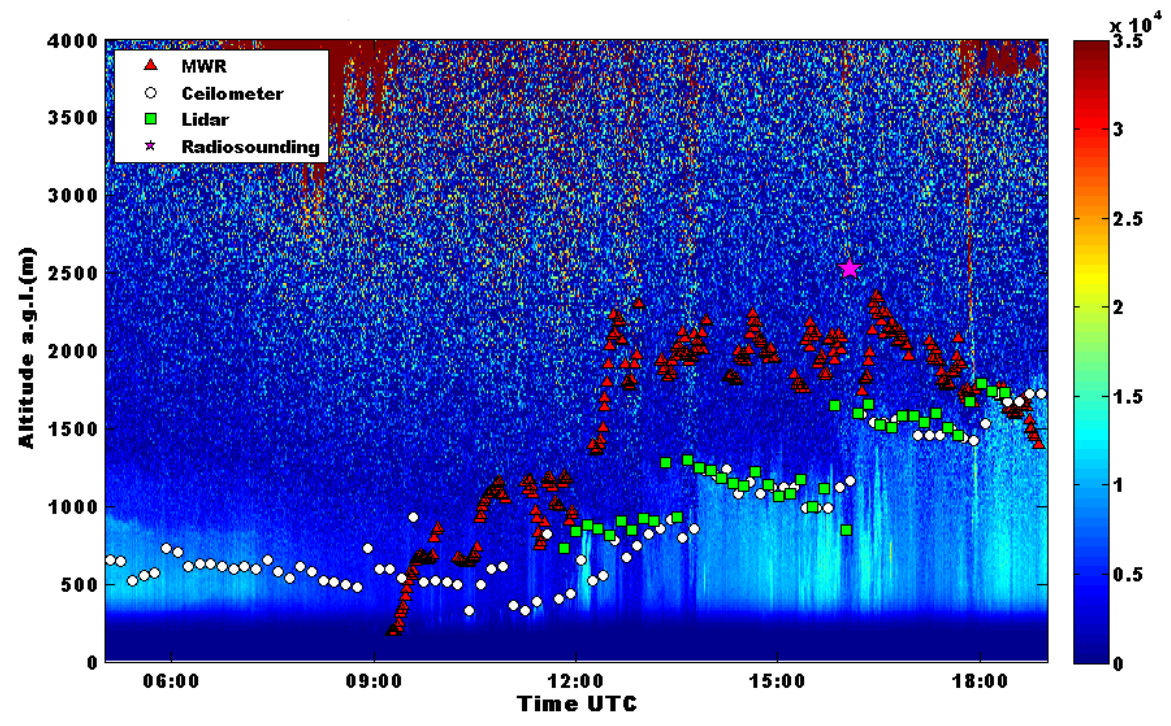

Fig. 3. Ceilometer RCS at $1064 \mathrm{~nm}$ (arbitrary units) on 07-May-2013. Marks represent PBLH estimation from different instruments according to the label.

\subsection{Examples: Daily PBL height evolution with different methodologies}

Finally, some case studies have been analyzed in detail. They evidence the agreementdiscrepancies between ceilometer and MWR retrievals of the PBLH. It is worthy to note the good agreement between MWR and radiosounding retrievals, both based on the parcel method, in spite of the rather low vertical resolution of MWR temperature profiles.

Figure 3 illustrates a fact that has been evidenced in the diurnal statistic presented in Fig. 2, the PBL grows at a slower pace from the point of view of the ceilometer and lidar (WCT method), being larger the PBLH estimated by the MWR. 


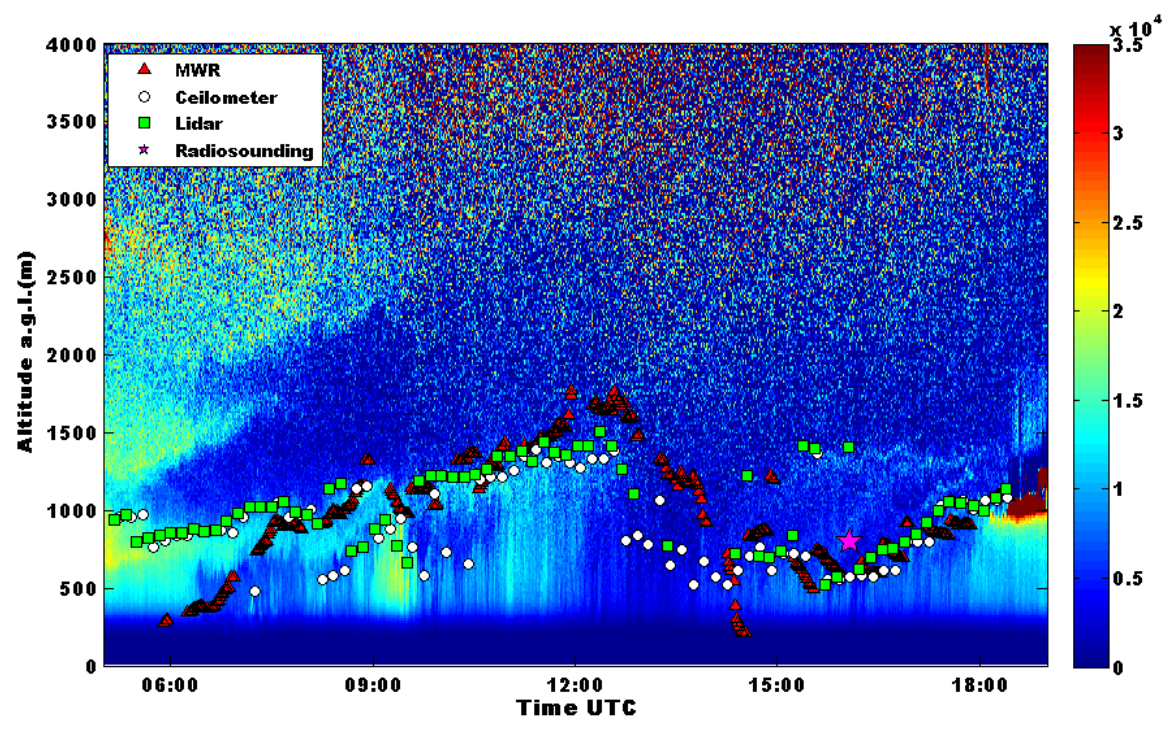

Fig. 4. Ceilometer RCS at $1064 \mathrm{~nm}$ (arbitrary units) on 17-Jun-2013. Marks represent PBLH estimation from different instruments according to the label.

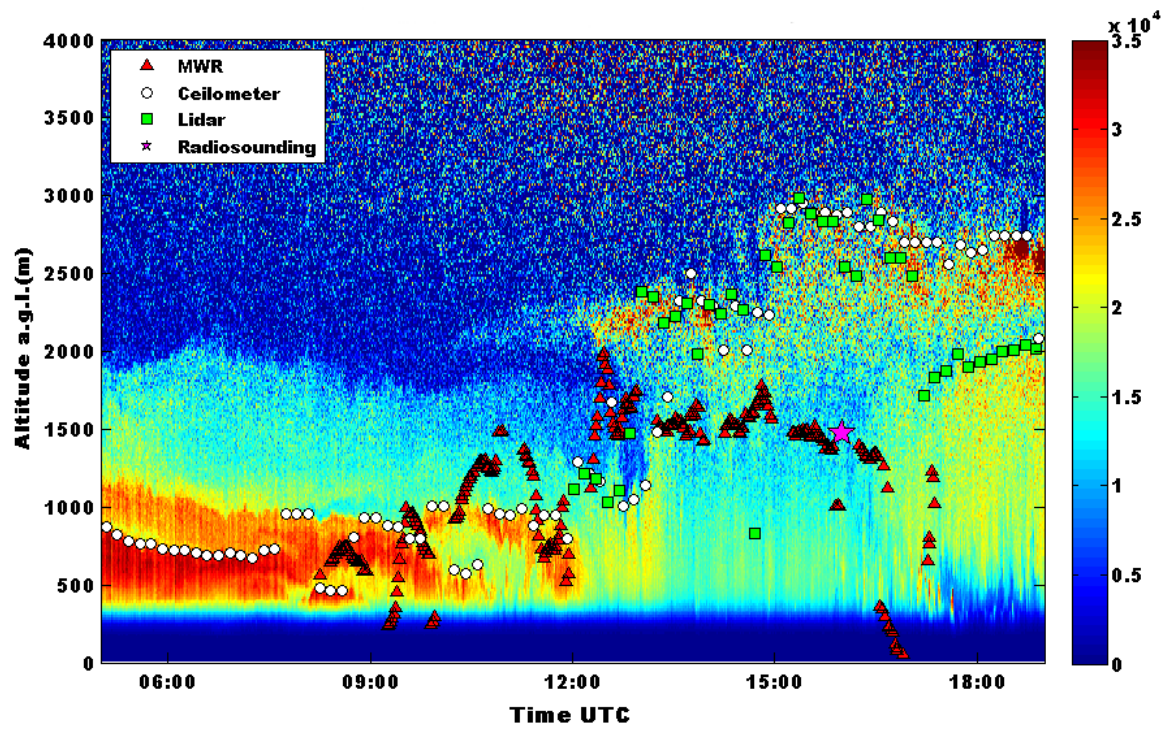

Fig. 5. Ceilometer RCS at $1064 \mathrm{~nm}$ (arbitrary units) 22-Jul-2013.Marks represent PBLH estimation from different instruments according to the label.

Good agreement on PBLH detection, between passive and active remote sensing instrumentation is encountered with partial cloudy conditions in Figure 4. Radiosounding data at 16:00 UTC confirm PBLH estimation from different methods. Around 15:00 UTC, several false PBLH detections were performed using lidar and ceilometer due to lofted layer of aerosol layers as it was indicated by [4].

Finally, Fig. 5 illustrates the rather large overestimation provided by ceilometers and lidar when lofted aerosol layer get mix with PBL. On the other hand, MWR estimation is according to radiosounding estimation at 16:00 UTC. So as previously stated, searching for a method to cope with the presence of lofted layer that subside and get mixed with the PBL represents a challenge to be solved with alternative approaches. A recent study indicates that the lidar depolarization could be a promising tool to determine the PBLH when lofted aerosol layer get mix with PBL [19]. 


\section{Conclusions}

PBLH has been retrieved by means of passive and active remote sensing. Differences between MWR and ceilometer retrievals are explained in terms of the basis of the methods. Ceilometer retrievals are based on the detection of the top of the aerosol layer, so erroneous detection are associated to the mixing of lofted aerosol layers in the free troposphere with the boundary layer. This is a frequent situation over our station during summer. On the other hand, the ceilometer detects the top of the residual layer early in the morning, when the convective PBL is not well developed. Both results evidence that the ceilometer PBLH retrievals present success and failures similar to those associate to lidar retrievals. Further work is ongoing to take advantage of the continuous measurements at high temporal resolution that can be obtained with these systems.

\section{Acknowledgements}

This work was supported by the Andalusia Regional Government through projects P10RNM-6299 and P12-RNM-2409; by the Spanish Ministry of Economy and Competitiveness through projects CGL2010-18782, CSD200700067, CGL2011-13580-E/CLI and CGL201116124-E; by the University of Granada through the contract "Plan Propio. Programa 9. Convocatoria 2013"; and by EU through ACTRIS project (EU INFRA-2010-1.1.16-262254). 